9alabra Clave • ISSN 0122-8285 • Volumen 13 Número 1 • Junio de 2010

\title{
Online Video Business Models: YouTube vs. Hulu
}

\section{Modelos de negocios de video en línea: YouTube vs Hulu}

\author{
Juan P. Artero ${ }^{1}$
}

\begin{abstract}
The origins and development of two of the most successful online video services in the United States: YouTube and Hulu, are examined in this paper. In looking into both these business stories, the case study analyzes the different commercial models implemented by the companies in question, the results in terms of web traffic and revenue, and the strategic outlook for both firms. YouTube develops a model that offers free videos on a global scale, but with local idiosyncrasies in the most important markets. It offers a large quantity of videos; however, in general, they are short in duration and poor in quality. In most cases, the videos are submitted and produced by the users themselves. This has the potential for creating technological problems (video streaming capacity will have to be high performance), legal difficulties (possible violations involving protected or inappropriate content) and commercial problems (reluctance among advertisers to insert ads in low-quality videos). Hulu concentrates on offering professional content free of charge and only on a national scale in the United States. The quantity of videos is much smaller; however, they generally are of longer duration and better quality. The videos are made available by the channels and the production companies that hold the rights to them. Consequently, Hulu faces fewer problems of a technological, legal and commercial nature, but its brand is not as well known, nor does it have the summoning power of YouTube.
\end{abstract}

Key words: Videos, idiossyncrasies, commercial models, United States.

\section{Resumen}

Los orígenes y el desarrollo de dos de los servicios de vídeo en línea con más éxito en los Estados Unidos: YouTube y Hulu se examinan en este documento. Al mirar ambas historias de negocios, este estudio de caso analiza los diferentes modelos comerciales aplicados, los resultados en términos de tráfico web e ingresos y la perspectiva estratégica para cada una. YouTube desarrolla un modelo que ofrece vídeos gratis a una escala global, pero con peculiaridades locales en los mercados más importantes. Tiene una gran cantidad de videos; sin embargo, en general, son de corta duración y de baja calidad. En la mayoría de los casos, presentados y producidos por los propios usuarios. Esto tiene el potencial para crear problemas tecnológicos (la capacidad de video streaming tendrá que ser de alto rendimiento), dificultades de orden jurídico (posibles infracciones con respecto a contenido protegido o inadecuado) y los problemas comerciales (reticencia entre los anunciantes a insertar publicidad en los vídeos de baja calidad). Hulu se concentra en la oferta gratuita de contenido profesional y sólo a escala nacional en los Estados Unidos. La cantidad de videos es menor y, por lo general, de mayor duración y mejor calidad. Los videos son puestos a disposición por los canales y las productoras que posee los derechos. En consecuencia, Hulu enfrenta menos problemas de carácter tecnológico, legal y comercial, pero su marca no es tan conocida, ni tiene el poder de convocatoria de YouTube.

Palabras clave: videos, idiosincrasias, modelos comerciales, Estados Unidos.

1 Ph.D. Public Communication. Professor, Universidad de Navarra, Recibido: $11 / 01 / 10$ Spain.jpartero@unav.es 


\section{Online Video Business Models: YouTube vs. Hulu}

The future of the television industry involves not only traditional transmission via the airwaves, cable or even mobile telephone, but also through the new channel open for video in recent years: the Internet. In the array of audiovisual content on the web, the suggestions are numerous and diverse. Nonetheless two models standout as paradigmatic and even opposite: YouTube and Hulu. Their origins, business models, content and perspectives represent two responses that, up to 1 now, have been contrary to the unknown consumption of legal audiovisual content through the Internet.

\section{Origin and Development of YouTube}

YouTube was founded in September 2005 by three former PayPal employees: Chad Hurley, Steve Chen and Jawed Karim. According to an anecdote, the founders used their personal credit cards to cover the firm's initial costs. YouTube is the world's leader in the market for online video. It allows users to upload and share videos through the Internet, via websites, mobile devices, blogs or e-mails. Anyone with Internet access is able to store and view videos on YouTube free of charge. Its corporative headquarters are located in San Bruno, California. According to Credit Suisse analysts, the company's losses in 2009 could amount to approximately 470 million dollars.

In November 2005, shortly after being founded, YouTube received 3.5 million dollars in financing from Sequoia Capital and was launched officially in December of that year, with Chad Hurley as CEO (Chief Executive Officer) and Steve Chen as CTO (Chief Technology Officer). Jawed Karim decided to return to his studies at Stanford University. In April 2006, the company received another eight million dollar investment from the same firm and in November 2006, bare- ly eleven months after being launched, YouTube was acquired by Google in exchange for 1.65 billion dollars in stock.

YouTube has reached several agreements on content with communication companies such as CBS, BBC and the music divisions of Universal, Sony and Warner. However, in March 2007, Viacom filed a one billion dollar lawsuit against Google and YouTube for presumed fraudulent use of protected content. Previously, it had presented a formal notice asking YouTube to remove approximately 100,000 videos from its site, specifically those with content belonging to one of the Viacom channels. In justifying its decision to sue, Viacom cited the need to prevent YouTube from continuing to deprive artists of royalties and to obtain compensation for the damage already done.

In June 2007, local versions of YouTube were launched in Brazil, Ireland, Italy, Japan, Holland, Poland, Spain and the United Kingdom. Apple's iPhone also began to include a YouTube application, increasing its share of the mobile phone market via an agreement reached with Verizon in November 2006.

In mid-2007, the firm launched several important innovations, one of which can be found in YouTube Invideo Ads, a commercial advertising stripe located in the lower part of the video. Advertisers are billed for each impression and the resulting revenue is shared with the video creator. Google also has included YouTube videos in its AdSense system. The owners of the websites that use AdSense are able to select videos from certain providers and the ads are shown in

YouTube is the world's leader in the market for online video. It allows users to upload and share videos through the Internet, via websites, mobile devices, blogs or e-mails. 
relation to the sites or the context of the video. The revenue is shared between the owner of the site, the video creator and Google.

In October 2007, the firm launched its YouTube Video Identification service to help legal owners protect their content. With this service, the content owners can upload complete copies to the service and YouTube servers will be responsible for searching the company's video catalogue to check if any other user has exercised those rights. The owners of the content then must choose between allowing YouTube to remove the videos in question or allowing it to introduce advertising and to share any revenue with the owner ${ }^{2}$.

In December 2008, YouTube had 100 million unique users in the United States. In October 2009 , one billion videos were viewed per day.

Attempts to examine the YouTube phenomenon basically involve three areas: sociological, technological and legal. The company's business outlook has been studied far less by academics. According to some authors, YouTube is a vehicle for individual public expression of what was once more private. In their opinion, it encourages the development of subcultures around a certain sense of community (Campos, 2007). Also, the collective behavior exhibited on YouTube suggests the site has adopted the role of public space, game field and cultural public sphere (Chu, 2009, pp. 337-353). Net surfers watch videos in search of information, and view and share them for entertainment, shared viewing and social interaction. Yet, even if web surfers watch videos for more or less the same reasons they watch television, YouTube has a distinctive social aspect; namely, its social connection to certain networks, groups or communities (Haridakis and Hanson, 2009, pp. 317-335).

The popularity of YouTube, coupled with the volume of data transmitted through the site,

2 http://www.crunchbase.com/company/youtube. fosters the expectation of a substantial growth in traffic. From a technical stand point, allowing anyone to publish content suggests that growth will not only exceed that of traditional websites and media, but will be sustainable as well. This will bring pressure to bear on the centralized and will require more decentralized approaches. Also, the larger amount of accessible references will reduce the effectiveness of strategies for personalized offer (Gill et ál., 2007, pp. 2426). Still, to be able to offer multimedia content at an acceptable speed remains a challenge for the future. Content storage and transmission are limited to different models, and delays can occur as a result of the user's geographical situation or the variables of the video itself, such as its age or popularity (Saxena et ál., 2008).

In legal terms, the controversy between YouTube and Viacom has complex implications for online video sites, the media, content creators and the general public (VerSteeg, 2007, pp. 4368 ). The problem with uploading videos illegally is that it can endanger the development of sites that contain user-generated content (UGC) (Cha et ál., 2007, pp. 24-26). However, the new distribution channels on the Internet give content creators an important advantage over the channels controlled by traditional media, provided their use of the legal media at their disposal is based on the doctrine of fair play (von Lohmann, 2007, pp. 128-133).

The biggest risk to any provider of user-generated content is that users might upload content that violates the copyrights of third parties or content that may be defamatory, obscene or inappropriate for minors. This could be potentially damaging to the company, but it does not seem to slow the growth of sites of this type (Holmes and Ganley, 2007, pp. 338-344). In fact, comments occasionally made about the law suits against YouTube ignore the fact that YouTube is already an integral part of the ecosystem of audiovisual rights. It will not be sacrificed 
simply because some users abuse the technology by uploading protected content without permission. However, according to some authors, this does not mean YouTube should be given a free pass, particularly because it can reduce the number of infractions at a low cost, without significantly interfering with legal use of the site (Lichtman, 2007, pp. 1-3).

One of the most extensive studies on the YouTube phenomenon poses an interesting critique on the rights of this platform. Following YouTube's own slogan (Broadcast Yourself) is a rather sarcastic postscript (as long as it is our content). The bottom line is clearly the possible exploitation of users for the benefit of the companies themselves (Wasko and Erickson, 2009, pp. 372-386).

\section{The Launching of Hulu}

Hulu was founded in March 2007 by NBC Universal and News Corporation, along with Providence Equity Partners. In April 2009, Disney became a shareholder, with each of the three media companies having a 27 per cent interest. In all, approximately 100 million dollars have been invested in the project. Today, Hulu is the third largest provider of videos on the Internet and its corporate headquarters are located in Los Angeles, California. Its chief executive is Jason Kilar and its CTO, Eric Feng.

The videos on Hulu are shown on their own player and with their own brand. In September 2007, Hulu acquired Mojiti, a Chinese company based in Peking, to use its technological platform as the base for Hulu's service. The site offers content from a dozen television channels and movie studios. By September 2008, it had as many as one hundred content providers. Its distribution partners include AOL, Comcast, MSN, MySpace and Yahoo.

There has been some confusion as to Hulu's rights to content belonging to NBC and News
Corporation. In principle, both companies have given Hulu exclusive rights to their content sent online through sites syndicated by third parties, such as MSN or AOL. The only exception to this exclusivity is NBC.com and others sites of both companies. Both may offer as much content as they wish on their own web sites and may do so free-of-charge. Accordingly, web surfers will find the same content on Hulu as on its syndicated sites and on the company's own web sites. In these cases, Hulu does not receive an income.

Hulu does have an exclusive right to make syndication deals with third parties. However, this has not prevented controversy, as was the case when contracts with platforms such as TV.com and Boxee.tv were cancelled in response to pressure from the channels (Prasad, 2009). NBC, for instance, was unable to establish deals on content distribution with operators such as Joost, Veoh and YouTube. The protected content does not include movies, sports or news. Hulu does not have exclusive rights to content of this type. Hulu's exclusivity does not include direct downloads of videos that will continue to be sold on iTunes, Amazon and similar sites. The exclusivity provision lasts for about two years. The other providers of content to Hulu's site, besides NBC and News Corporation, are not exclusive.

With regard to income distribution, the content provider retains 70 per cent of gross revenue generated by the ad; the distribution partners (third-party syndicated sites), if any, keeps 10 per cent; and Hulu receives about 20 or 30 per cent, depending on whether or not there are third parties. The sales forces of NBC and News Corporation may sell ads through specific channels and specific programs. However, Hulu's sales force only is allowed to sell according to genre, as opposed to a specific channel or program. The main reason is to protect the price politics established individually by each broadcasting company (Blodget, 2007). 
Volumen 13 Número 1 • Junio de 2010

Contrary to YouTube, Hulu is a project that was launched through television channels. It is not an innovation created by visionary students. Its content is professional, rather than userproduced videos. It was well-financed from the beginning, not in the style of a micro-SME. The majority of its videos feature ads, as opposed to only a few. And, for reasons related to cultural aspects and international rights, it has chosen to restrict its distribution to the United States. It does not have the global scale of the Internet.

\section{Results: Traffic vs. Revenue}

Given these initial elements and a similar amount of time in cyberspace (although YouTube started about 18 months before Hulu), the data in terms of videos served and unique users in the United States are quite different.

\section{Video Platforms in the United States per Videos Served in March 2009}

\begin{tabular}{|l|r|r|}
\hline \multicolumn{1}{|c|}{ Platform } & \multicolumn{1}{c|}{$\begin{array}{c}\text { Videos } \\
\text { (thousands) }\end{array}$} & $\begin{array}{c}\text { Video } \\
\text { quotas }\end{array}$ \\
\hline Total Internet & $14,468,345$ & 100.0 \\
Google Sites & $5,919,530$ & 40.9 \\
Fox Interactive Media & 437,098 & 3.0 \\
Hulu & 380,102 & 2.6 \\
Yahoo Sites & 334,724 & 2.3 \\
Microsoft Sites & 288,239 & 2.0 \\
Viacom Digital & 277,753 & 1.9 \\
CBS Interactive & 191,686 & 1.3 \\
Turner Network & 167,323 & 1.2 \\
Disney Online & 125,248 & 0.9 \\
AOL & 105,237 & 0.7 \\
\hline
\end{tabular}

Source: comScore Video Metrix

In an overwhelming way, YouTube is still the number one video service on the Internet. The Google sites, as a whole, provide 40.9 per cent of all the videos reproduced in the American market, while the Fox sites, especially MySpace TV, account for only 3 per cent. In March 2009,
Video Platforms in the United States per Unique Users in March 2009

\begin{tabular}{|l|r|c|}
\hline \multicolumn{1}{|c|}{ Platform } & $\begin{array}{c}\text { Unique users } \\
\text { (thousands) }\end{array}$ & $\begin{array}{c}\text { Media } \\
\text { Videos } \\
\text { per user }\end{array}$ \\
\hline Total Internet & 149,410 & 96.8 \\
Google Sites & 100,382 & 59.0 \\
Fox Interactive Media & 55,156 & 7.9 \\
Yahoo Sites & 42,524 & 7.9 \\
Hulu & 41,564 & 9.1 \\
CBS Interactive & 35,400 & 5.4 \\
Microsoft Sites & 32,194 & 9.0 \\
Viacom Digital & 27,168 & 10.2 \\
AOL & 22,349 & 4.7 \\
Turner Network & 19,644 & 8.5 \\
\hline
\end{tabular}

Source: comScore Video Metrix

Hulu's share was only of 2.6 per cent, although later measurements show it is ahead of Fox and is now the second largest online video platform in the United States.

The number of videos served was 380 million a month in the case of Hulu, and approximately 5.9 billion in the case of YouTube and other Google sites. However, it is estimated that only three per cent of the videos on YouTube generate income through ads. This represents 177 million videos monetized, half of the 380 million on Hulu. Also, Hulu's revenue during its first year could have come to about 90 million dollars, which is the same amount Bear Stearns estimated for YouTube in American territory for the 2008 financial year.

In terms of unique users, YouTube and other Google sites tallied 100 million views in American territory. In March 2009, Hulu reached 40 million viewers. Yet, the fundamental difference resides in the number of videos viewed by each user: 59 videos per user on Google sites and nine videos per user on the Hulu site. This figure is 
justified by the essential difference in duration between one video and another.

In terms of revenue, the prospects for growth in the number of ads in online videos in the United States seem to be quite encouraging.

\section{Advertising Investments in Online Videos in the United States 2001-2002}

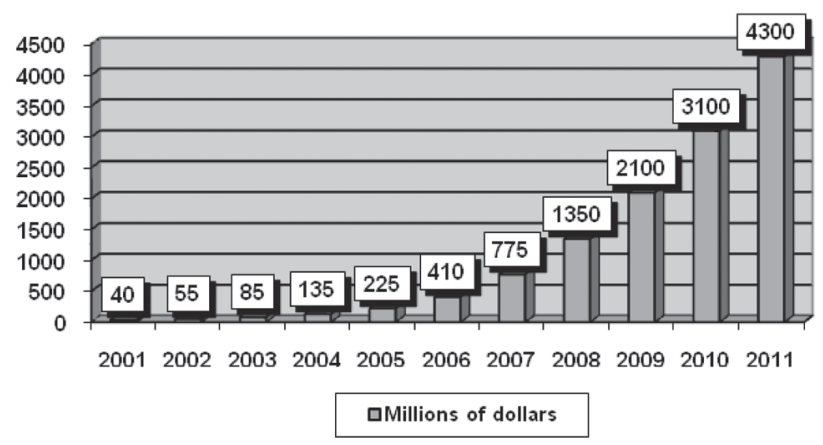

Source: eMarketer.

According to these estimates, advertisers will invest 2.1 billion dollars in online videos during 2009, 3.1 billion during 2010 and 4.3 billion in 2011. However, although YouTube controls more than 40 per cent of the market, it apparently does not have an advertising quota above 15 per cent. Hulu could be an alternative option in this case: a smaller quota in terms of traffic, but a larger one in terms of revenue.

\section{Cable's Response}

In addition to this situation, it is important to highlight the reaction of cable operators, who are very powerful in the United States and do not want to fall behind in content distribution through the Internet. Comcast and Time Warner announced an ambitious pilot program to convince their clients that television on the Internet should not be free of charge. Through a service called TV Everywhere, these companies will give their clients access to Premium content via broadband and eventually through mobile telephones.
The pilot test began with 5,000 Comcast subscribers who had computer access to the Time Warmer channels TNT and TBS and to the same video catalogues available from these channels through their cable decoders. This means cable subscribers, with their current subscription, can enjoy content on more screens at no extra charge and without the need for new technological equipment. Still, as more consumers adopt TV Everywhere, they can expect to be billed at a higher price.

At the same time, consumers who prefer to pay only their Internet provider and to consume videos online via free sites financed with ads, such as Hulu, might be annoyed, since TV Everywhere represents an alternative and a possible threat to the Hulu model.

If the pilot program is successful and proves to have a safe user authentication system, Comcast and Time Warner expect other television programmers, mobile telephone operators and Internet providers will unite, giving cable subscribers a way to watch the content they pay for on television via any computer connected to broadband or an authenticated mobile telephone.

About 92 per cent of Americans who subscribe to cable will access this system. For them, TV Everywhere offers a potential advantage. The question is whether they will continue to pay for the old cable subscription system, as they gradually consume more and more via the online connection.

Nothing can prevent television channels from placing their content on Hulu and on TV Everywhere, as the contracts for the latter will not be exclusive. Nonetheless, since they can choose between both systems, programmers might find the second option more convenient, as it maintains yesterday's lucrative model on today's new platforms (van Buskirk, 2009). 


\section{Strategic Analysis: Hulu}

During its Beta phase, Hulu was labeled by the technological press as a future failure. Most found it ridiculous that a free online video site launched by major media companies such as NBC and Fox would be able to offer a good user experience, much less become successful. After all, most successful companies on the Internet, such as Google, YouTube, Facebook and MySpace, were not launched by existing media enterprises.

However, Hulu has been a success from the beginning. One of the strong points in the Hulu project is an easy and intuitive user interface that offers videos without the need for a separate application; another is an extensive catalogue of free content (from several providers in addition to Fox and NBC), not to mention a good search engine to find what you are looking for. Furthermore, Hulu had enough key assets to begin with, but not so many as to prevent the business model and the corporate culture of the founding companies from exerting too many constraints.

The bulk of Hulu's success is credited to the company's CEO, Jason Kilar. The initial idea that Fox and NBC should be associates came from Jeff Zuckers, the CEO at NBC Universal, and Peter Chernin, the President of News Corporation, Fox's parent company. However, one of their initial steps was to hire an outside executive for the new project. Kilar had worked for Amazon, where he helped the company to expand its book business to include videos. The first thing he did when he took over the project was to divest Hula of the executives and consultants Fox and NBC offered to provide support. He also did away with the initial plan to subcontract the site's design and information technology codes. Kilar understood that technology was his competitive advantage and, as such, it was important that Hulu be able to create every code line of its web site. Kilar shaped Hulu according to his vi- sion of a successful online video site, convincing the executives at Fox and NBC in the process. He was able to gain their confidence and support, which was all he needed, apart from their companies' video content.

The new challenge facing Hulu is to combine its innovative approach to content with an equally innovative business model. Its model is basically the same as the one used by traditional channels; namely, to offer content that generates audiences and to sell those audiences to advertisers. However, the cost per 1,000 in the case of Hulu is two or three times higher than for the channels.

Hulu claims its most successful programs are downloaded millions of times each month, but a series such as CSI can reach 16 million television viewers in a single night. And, Hulu only sells two minutes for every half hour program, while the more traditional operators sell eight minutes, on an average, for the same length of time. $\mathrm{Hu}-$ lu's audience continues to grow; however, due to the economic crisis in the market for online video advertising, Hula had less of a turnover in December 2008 than in previous months.

Apart from possible worries about profitability, Hulu offers an alternative to the main channels, which are faced with the possibility of users obtaining their content illegally from the Internet. In fact, this might be of Hulu's main accomplishment; namely, having distanced itself from its parent companies and their business model (Hopkins, 2009).

In fact, its own model is not a closed matter. The CEO of News Corporation, Chase Carey, recent-

The new challenge facing Hulu is to combine its innovative approach to content with an equally innovative business model. 
ly said that Hulu should begin to charge for some of its content, because financing based solely on ads could turn out to be complicated, as the scenario is becoming more and more fragmented. Hulu has begun to offer links to Amazon for users who want to buy digital downloads from the programs they can watch on the website. Other television sites on the Internet also are including links to digital sale sites or DVD sites in an effort to channel a certain amount of revenue in that direction (Netherby, 2009, p. 5).

\section{Strategic Analysis: YouTube}

Some believe it was wrong for Google to buy YouTube, due to copyright violations and the financial support from Google that gave right holders the momentum to sue the online video site. Others believe Google's decision to enter the online video market and to become a quasi content provider was not the best way to take advantage of the explosion of ads in online videos. In any case, Google is now in the business and YouTube is the central element of its strategy.

YouTube might be tremendously popular, but its ability to generate revenue is at least doubtful. Google spent 1.65 billion dollars on the acquisition and, so far, it has had to find a way to monetize the traffic and to obtain a positive return on that investment.

The estimates on YouTube revenue vary. Forbes estimates 390 million dollars for 2009, while Citi analysts believe it could be as high as 500 million dollars. However, YouTube's advertising department will have to improve many things to reach that level. In theory, little has been done to reduce the fears expressed by advertisers regarding the site's content. The question is whether the business can be as successful as the website.

In the opinion of some analysts, YouTube could become a company that redefines the audiovisual advertising business. It has been at the right place at the right time. But now, it needs to change and move on; in some way, this requires an agreement with the big content corporations. Video now represents about 60 per cent of the traffic on the Internet, and there are those in the marketing and advertising world who would like YouTube to be successful in leading a revolution to break down the barriers imposed by television companies. The question is whether or not YouTube will be able to pull it off. It should remember it is not the only company offering this service. Making sure the business models work and guaranteeing a capacity for innovation seem to be the main keys to YouTube's future (Strategic, 2007, pp. 22-24).

\section{Comparing Strategies}

In contrast to YouTube, Hulu does not have to worry about copyright issues, or about the fact that the content submitted by users might be inappropriate. All its content can attract advertisers. Indeed, most advertising for online video appears in episodes of series from the big channels shown on Hulu, ABC.com and CBS.com. It is a format the advertisers understand and accept.

This understanding on format is just one of Hulu's advantages. In contrast to many videos on YouTube, Hulu does not cross the boundary of decency as frequently and the demographical data is readily available. For this reason, Google launched Insight, a service that provides statistics on videos to help out with demographical data.

If YouTube has proved something, it is the existence of an enormous market for user-submitted content. However, from a business standpoint, professional content is where advertisers want to put their money and is the way video services will be able to strengthen their financial position. Although Hulu probably never will be as large as YouTube or Google, it can use its size for its benefit. The advantage Hulu has is its capacity to direct advertisers to the content that will do the most to attract a target audience. 
Volumen 13 Número 1 • Junio de 2010

The essence of the question is the value of breadth and depth as opposed to niche. Advertisers want to advertise in the videos they know their target audience is watching. YouTube has taken some steps with regard to professional content, but has yet to solve the problem of making money with its expensive user-generated content, which accounts for the majority of its videos. These also are the ones advertisers are more reluctant to use.

Let us not forget that Hulu is still in an incipient phase and much can happen before it evolves into a strong brand. However, it is rapidly becoming the site where traditional channels and movie studios now want to offer free content, despite having been reluctant to do so in the past. And, YouTube is still an enemy in their eyes, because of its problems with respect to exploiting the rights of content owners.

To reduce the Hulu menace, Google would have to make its video inventory more attractive to advertisers. However, if YouTube does not increase its professional content and fails to improve the monetization of user-generated content, Hulu could consolidate financially and become one of the most profitable companies in the industry (Reisinger, 2008).

Hulu also shows how difficult it can be to administer a project that is common to several competitors. For example, there are apparent discrepancies between Hulu's sales team and those of its parent channels ABC, NBC and Fox. In theory, Hulu's prices are high (about 40 dollars per thousand), but the channels complain Hulu's commercial representatives sometimes sell categories at a lower price than what is offered to the channels. The channels can leave the project anytime they want and, so far, CBS has chosen not to join.

Hulu's estimated revenue for 2009 is 120 million dollars, although its losses have been calculated
To reduce the Hulu menace, Google would have to make its video inventory more attractive to advertisers. However, if YouTube does not increase its professional content and fails to improve the monetization of user-generated content, Hulu could consolidate financially and become one of the most profitable companies in the industry (Reisinger, 2008).

at around 33 million dollars. One dark cloud on the horizon is the possibility of a prior subscription of some sort being required, which is the battle in which cable operators like as Comcast are involved. Another is the possibility that this same operator might buy NBC Universal, in which s case Comcast could deprive Hulu of one of its principle providers and reserve its TV Everywhere platform for authenticated users (Shields, 2009).

A look at the industry in light of content sources, distribution and devices, shows four main business models:

1) Traditional media: A model based on brand content created by professionals and distributed through an environment with conditioned access and specific devices. This is where the most established communication companies operate nowadays.

2) Closed communities: A model based on the distribution of user-generated content behind a wall or around conditioned access through specific devices. Typically, these are traditional businesses that allow users to make contributions; they also have certain nontraditional features. For instance, NTT DoCoMO has approximately 95,000 communities accessible through the service on its devices. And, Comcast recently announced 
a deal with Facebook to produce a television series with videos submitted by users.

3) Hyper-syndication of content: A model that allows access to professional content through open channels, without devices or specific access providers. The examples mentioned here include the American channels that offer content through their own websites or on Hulu.

4) Aggregation platforms: A more extreme model based on user-generated content and open distribution platforms. It is the most disruptive model, as neither traditional producers nor distributors have advantages. Here, the aggregators are directed basically towards users such as YouTube, MySpace or Second Life.

As for the next few years, there is no clear winner among these four business models. In fact, different companies can be expected to choose between various models and unique combinations that value their strengths and traditional assets. Consequently, the outlook for the market is extremely varied and even chaotic (Berman et ál., 2007, pp. 23-30).

Yet, there is no doubt the Internet will become an ever more important platform for video distribution to users. In turn, video is expected to garner an increasing proportion of Internet traffic. This situation offers new online content providers and distributors an opportunity to reach a large audience effectively. But, it also poses challenges to traditional producers and distributors, who are losing control over what users watch, where and how, including their own protected content. This confrontation between opportunities and challenges for video production and distribution on the Internet also will manifest itself in legal aspects. The junction between growth in broadband connection and the innovative methods used to create and distribute videos online will continue to pose important challenges to the business model used by the major producers and distributors of protected content and to the laws designed to safeguard that content (Meisel, 2009, pp. 1-16).

With three and a half hours average viewing, the major players in the audiovisual sector seem to be relatively untroubled by the practices of communities on the Internet with respect to usergenerated content. Moreover, producers see this phenomenon not as an emergency situation requiring the establishment of a communal model for content distribution, but more as another form of piracy. Yet, the question is whether this model can be ignored, if it has become so easy for people to create, circulate their creations and construct their own programs. Young spectators are abandoning television in favor of the Internet, given the pleasure to be derived from appropriating content in their own way, the use of which is being regulated through efforts at legislation on intellectual property (Mabillot, 2007, pp. 39-49).

Undoubtedly, in recent years, video distribution sites on the Internet have moved from a more marginalized position to the very center of the media specter. Often, the videos that are available include a mixture of user-generated and professional content. Television channels fear the availability of their content on the Internet will have a negative impact on television consumption. Having witnessed the growth of relatively independent video sites such as YouTube, television channels have responded by offering their content on sites of their own or on joint sites such as Hulu. The effects of distribution via the web are evident in traditional television consumption patterns, especially among the younger population. However, despite some evidence that traditional consumption is being substituted by viewing on the Internet, the amount of time invested in watching a program on the web largely exceeds the minimum reduction in traditional viewing. The time invested is longer than before, if one combines conventional television 
viewing with viewing of the websites of television channels (Waldfogel, 2009, pp. 158-168).

\section{Conclusion}

In short, YouTube and Hulu show the strengths and weaknesses of the two models being used to capture audiences and to make the increasing consumption of audiovisual content on the Internet profitable.

YouTube bases its strategic proposal on a model that offers free videos on a global scale, but with local idiosyncrasies in the most important markets. It offers a large quantity of videos, but they generally are of short duration and poor quality. The videos are submitted by users and, in most cases, are produced by users themselves. This can create technological problems (the capacity for video streaming will have to be high performance), as well as legal difficulties (possible violations involving protected or inappropriate content) and commercial problems (reluctance of the advertisers to insert ads in low- quality videos).

Hulu concentrates on offering professional content free of charge and only on a national scale in the United States. The quantity of videos is much smaller, but they are generally longer in duration and better in quality. They are made available by the channels and production companies that hold the rights to them. This means a far fewer technological problems and violations of legal and commercial rights, but the Hulu

In short, YouTube and Hulu show the strengths and weaknesses of the two models being used to capture audiences and to make the increasing consumption of audiovisual content on the Internet profitable. brand has neither the scope nor the summoning power of YouTube. The fundamental problem for Hulu is that it cannot aspire to become a global site, because of the damage that would be inflicted on the enormous business of assigning television and movie rights to other countries where their own content providers are located.

Another point to consider is that both proposals begin by offering users content free of charge. This aspect is questioned by the model for audiovisual consumption on the Internet being used by Amazon, iTunes, Netflix or TV Everywhere, which is based on user payment. And, despite attempts to the contrary by companies and governments, the illegal downloading of files is still very relevant, apart from piracy involving traditional sources.

If there is one thing all these proposals have in common, it is the fact that profitability of the new models for audiovisual business generally has yet to be proven. This is true of both YouTube and Hulu. However, for the most part, the traditional business models used for open and pay television are still profitable. But technological advancement (in most cases, current bandwidth does not allow for optimal viewing) and the changes in consumer habits (mainly migration towards the Internet for audiovisual consumption by younger audiences), coupled with uncertainty regarding the capacity of the law to reign in piracy, justify the attempts to find new strategic options for the traditional audiovisual industry.

The question is whether the new window to audiovisual consumption; that is, the Internet, will end up being dominated by traditional operators (the major communication groups) or be taken over by new ones. In the past, the former have been able to control the production of content by controlling distribution, which is exactly what the new operators are trying to do via the 
Internet. However, the audiovisual media are reluctant to become trapped by the new operator's distribution networks; they know constraints to access would deprive them of their competitive advantage.

Like Google, YouTube is a new operator who tries to "monopolize" the user with content from others. Hulu is an attempt by traditional operators to defend their own distribution networks, also on the Internet. The operators who charge for their service turn to the Internet to continue to sell content, but now in a different way. In the end, the traditional competitive battle has moved into the new realm of the Internet, but with novel and uncommon competitors challenging the traditional industry. Now, it is they and not the usual operators who supposedly monopolize the distribution networks.

The corner stone will lie with the capacity of these new models to contribute not just traffic, relevance or users, but revenue, which is essential to the survival of any company. In fact, the latest news seem to indicate that Hulu is now closer to second place (912 million videos served) in the American online video market, following YouTube (11.2 billion videos), and could take advantage of its strategic position to charge for its content. This would give Hulu an opportunity to become the entertainment industry's top online premium content website, supported by both advertising and subscriber fees (McIntyre, 2010).

\section{References}

Berman, S. J., S. Abraham, B. Battino, L. Shipnuck, and A. Neus (2007). New Business Models for the New Media World. Strategy and Leadership, 35 (4).

Blodget, H. (2007). Hulu's 'Exclusivity' and Business Model Explained. The Business Insider. October 23. Disponible en http://www.businessinsider.com/2007/10/hulus-exclusivi
Campos, J. M. (2007). “Brocadas Yourself! Identidad, comunidad y masas inteligentes para la nueva Sociedad del Conocimiento". Icono, 14 (9), June, www.icono14.net

Cha, M., H. Kwak, P. Rodríguez, Y-Y. Ahn, and S. Moon (2007). I Tube, You Tube, Everybody Tubes: Analyzing the World's Largest Usergenerated Content Video System. IMC'07. San Diego, October.

Chu, D. (2009). Collective Behavior in YouTube: A Case Study of ‘Bus Uncle' Online Videos. Asian Journal of Communication, 19 (3), September.

Gill, P., M. Arlitt, Z. Li, and A. Mahanti (2007). YouTube Traffic Characterization: A View from the Edge. IMC'07. San Diego, October.

Haridakis, P. and G. Hanson (2009). Social Interaction and Co-Viewing With YouTube: Blending Mass Communication Reception and Social Connection. Journal of Broadcasting and Electronic Media, 53 (2), June.

Holmes, S. and P. Ganley (2007). User-generated Content and the Law. Journal of Intellectual Property Law \& Practice, 2 (5).

Hopkins Callahan, R. (2009). Hulu is a Big Hit. Forbes.com, January 22. Disponible en http://www.forbes.com/2009/01/22/huluamazon-newscorp_leadership_clayton_in_ rc_0121claytonchristensen_inl.html

Lichtman, D. (2007). YouTube's Future - And Yes, It Has One. The Progress \& Freedom Foundation's Center for the Study of Digital Property, Bulletin 2.3, December.

Mabillot, D. (2007). User Generated Content: Web 2.0 Taking the Video Sector by Storm. Communication E Strategies, 65. 
McIntyre, D. E. (2010). Hulu Finally Starts to Menace YouTube. WallSt.com, April 13. Disponible en http://247wallst.com/2010/04/13/hulu-finally-starts-to-menace-youtube/

Meisel, J. B. (2009). Economic and Legal Issues Facing YouTube and Similar Internet Hosting Web Sites. Journal of Internet Law, 12 (8). February.

Netherby, J. (2009). Hulu Forges Amazon Links. Video Business, 29 (35), September 14.

Prasad, W. N. (2009). Hulu.com. A New Business Model for Online Video? Hyderabard, India: Center for Management Research (ICMR).

Reisinger, D. (2008). Can Hulu Be A Bigger Business Than YouTube? TechCrunch. September 1. Disponible en http://www.techcrunch. com/2008/09/01/can-hulu-be-a-bigger-businessthan-youtube/

Saxena, M., U. Sharan, S. Fahmy (2008). Analyzing Video Services in Web 2.0: A Global Perspective. NOSSDAV'08. Germany: Braunschweig.

Shields, M. (2009). Growing Pains at Hulu. Mediaweek. November 15. Disponible en http:// www.mediaweek.com/mw/content_display/ news/digital-downloads/broadband/e3i8f2c0287dc37ec6baf6209f20ced7140

Strategic Direction (2007). Innovation - Luck or Judgment? Microsoft and YouTube Make the Right Moves, 23 (8).

van Buskirk, E. (2009). Cable Departs from Hulu Model with 'TV Everywhere'. CNN.com/ technology, June 26. Disponible en http://www. cnn.com/2009/TECH/biztech/06/26/wired. tv.everywhere/index.html

VerSteeg, Russ (2007). Viacom v. YouTube: Preliminary Observations. North Carolina Journal of Law and Technology, 9 (1), Fall.

von Lohmann, F. (2007). Fair Use, Film, and the Advantages of Internet Distribution. Cinema Journal, 46 (2), Winter.

Waldfogel, J. (2009). Lost on the Web: Does Web Distribution Stimulate or Depress Television Viewing? Information Economics and Policy, 21.

Wasko, J. and M. Erickson (2009). The Political Economy of YouTube. In P. Snickars, and P. Vonderau. The YouTube Reader. Stockholm: National Library of Sweden. 